\title{
PENGARUH PROMOTIONS MIX TERHADAP KEPUTUSAN MENGINAP TAMU DI HOTEL SANTIKA PREMIERE SLIPI, JAKARTA
}

\section{[Effect of Promotions Mix With Guest Stay Decisions At Santika Premiere Slipi, Jakarta]}

\author{
Yulianti T. Runi ${ }^{1)}$, Triandi ${ }^{2)}$ \\ 1)Hospitaliti \& Pariwisata, Universitas Matana \\ 2) Hospitaliti \& Pariwisata, Universitas Matana \\ Diterima Februari 2022 / Disetujui Februari 2022
}

\begin{abstract}
ABSTRACK
Researchers want to examine the effect of the promotion mix on the decision to stay at the Santika Premiere Slipi Jakarta. The results of multiple linear regression analysis show that advertising has no significant effect on the decision to stay, then sales promotion, personal selling, public relations, and direct marketing have a significant effect on the decision to stay. This can be shown by Fcount of 124.830 with Fcount probability of

$0.000<0.05$. The amount of the contribution of the 5 independent variables together to the decision to stay is $62.2 \%$. While $37.8 \%$ is influenced by other variables that are not tested by this study. This study shows that individually the four variables, namely sales promotion, personal selling, public relations, and direct marketing have a significant influence on the decision to stay, only advertising has no significant effect on the decision to stay. The results of this study indicate that direct marketing is the most dominant influence on the decision to stay.
\end{abstract}

Keywords: Promotional Mix, Advertising, Sales Promotion, Personal Selling, Public Relations, Direct Marketing, and Decision to Stay

\begin{abstract}
ABSTRAK
Penelitian ini dilakukan untuk melihat pengaruh bauran promosi terhadap keputusan menginap yang terjadi di Santika Premiere Slipi Jakarta, Hasil analisis regresi linear berganda menunjukan bahwa advertising tidak berpengaruh signifikan terhdap keputusan menginap, kemudian sales promotion, personal selling, public relations, dan direct marketing berpengaruh signifikan terhadap keputusan menginap. Hal ini dapat diperlihatkan dengan Fhitung sebesar 124,830 dengan Fhitung probabilitas sebesar $0,000<0,05$. Besarnya kontribusi dari 5 variabel bebas tersebut secara bersama-sama terhadap keputusan menginap ialah $62,2 \%$. Sedangkan $37,8 \%$ dipengaruhi oleh variabel-variabel lain yang tidak diuji oleh penelitian ini. Penelitian ini memperlihatkan bahwa secara individual keempat variabel, yaitu sales promotion, personal selling, public relations, dan direct marketing memiliki pengaruh yang signifikan terhadap keputusan menginap, hanya advertising yang tidak berpengaruh signifikan terhadap keputusan menginap. Hasil penelitian ini menunjukkan bahwa direct marketing adalah yang paling memiliki pengaruh dominan terhadap keputusan menginap.
\end{abstract}

Kata kunci :Bauran Promosi,Advertising, Sales Promotion, Personal Selling, Public Relations, Direct Marketing, dan Keputusan Menginap

\author{
*Korespondensi Penulis: \\ E-mail: \\ runiyulianti@matanauniersity.ac.id
}

\section{PENDAHULUAN}

Pemasaran merupakan suatu proses serta aktivitas hubungan mengenai kebutuhan dan keinginan yang harus dipenuhi bagi konsumen yang berusaha diberlakukan 
produsen dengan sistem yang tepat. Bilamana suatu industri atau perusahaan bersikeras untuk bertahan dalam persaingan ekonomi yang erat tersebut, pemasaran adalah suatu hal yang harus diperhatikan. Karena dari waktu ke waktu, situasi pasar akan terus berubah maka diperlukan perilaku perusahaan dalam menyiapkan segala keingin dan kebutuhan pasar (Raharta, 2017).

Dalam peningkatan dan memperoleh laba yang positif, para visioner bisnis wajib memiliki teknik untuk memiliki pilihan untuk mempertahankan organisasi mereka dan menyaingi berbagai pesaing yang sibuk dengan bidang yang sama. Untuk mengukur pencapaian suatu penginapan dalam menjual barang fundamentalnya, khususnya kamar, dapat disimpulkan dari besar kecilnya tingkat penghuni hotel. Tingkat hunian kamar adalah suatu kondisi seberapa banyak kesepakatan kamar tercapai, dibandingkan dengan banyaknya kamar yang dapat diakses. Metodologi yang ditampilkan sangat penting untuk mendapatkan dan memperluas pembayaran organisasi, seperti yang diungkapkan oleh (Kotler \& Keller, 2009) dalam Aprilukito, Simatupang, \& Suparman, (2017).

Promosi adalah siklus sosial di mana orang dan pertemuan mencapai segala sesuatu yang diinginkan serta diperlukan oleh konsumen melalui membuat, mempromosikan, dan tanpa syarat memperdagangkan product dan administrasi yang gunanya signifikan oleh konsumen. Periklanan adalah bagian inti dari suatu organisasi atau perusahaan, terutama di bidang keramahan, sehingga ada kantor yang tugasnya untuk memasarkan dan menemukan klien, khususnya Sales dan Marketing. Sales dan Marketing mempunyai peran yang sangat krusial di dalam industri atau perusahaan, terutama di bidang penginapan karena menjadi tolak ukur bagi sebuah penginapan untuk memperoleh penghasilan. Salah satu tugas Transaksi dan Promosi adalah membuat pengaturan periklanan dan menyebarkan kegunaan produk kepada klien. Dalam Promosi harus memiliki beberapa sudut yang terkandung di dalamnya sehingga dapat dilakukan secara efektif dan efisien adalah membuat pengaturan periklanan dan meningkatkan item kepada klien, dalam Promosi harus memiliki beberapa sudut pandang yang terkandung di dalamnya sehingga latihan periklanan dapat diselesaikan dengan sukses dan produktif (Aprilukito, Simatupang, \& Suparman, 2017).

Komunikasi pemasaran terintegrasi memperluas promosi dan mencakup semua cara konsumen berkomunikasi dengan organisasi / group. Ini tidak terbatas pada media tradisional dan surat langsung, tetapi juga mencakup pengemasan, demonstrasi produk di toko, literatur penjualan, media online, dan interaktif. Keberhasilan program promosi dengan bantuan elemen komunikasi pemasaran terintegrasi bergantung pada kemampuan pengembangnya untuk mengidentifikasi anggota audiens dan memahami apa yang mereka inginkan (Juska J., 2017) dalam buku (Nasrullah, et al., 2020). Memberikan informasi pada seller serta buyer dengan metode, seperti menyiarkan fakta, merayu, dan membujuk pemakai dalam hal meningkatkan keputusan konsumen dalam mengambil pilihan dalam barang atau jasa yang diberikan merupakan tujuan dari promosi. Aspek marketing memiliki promotion mix yang dimaksudkan untuk memperkenalkan barang atau jasa supaya pengguna mengetahui barang dan jasa yang diberikan. PromotionalMix Tool dibagi menjadi periklanan (advertising), 
promosi penjualan (sales promotion), penjualan pribadi (personal selling), publisitas (public relations), dan pemasaran langsung (direct marketing) (Molika, Abdillah, \& Pangestuti, 2017). Gambar 1. Tingkat Penghunian Kamar (TPK) Hotel Bintang 2016 vs 2017 Sumber: (Pusat Data dan Sistem Informasi, 2018)
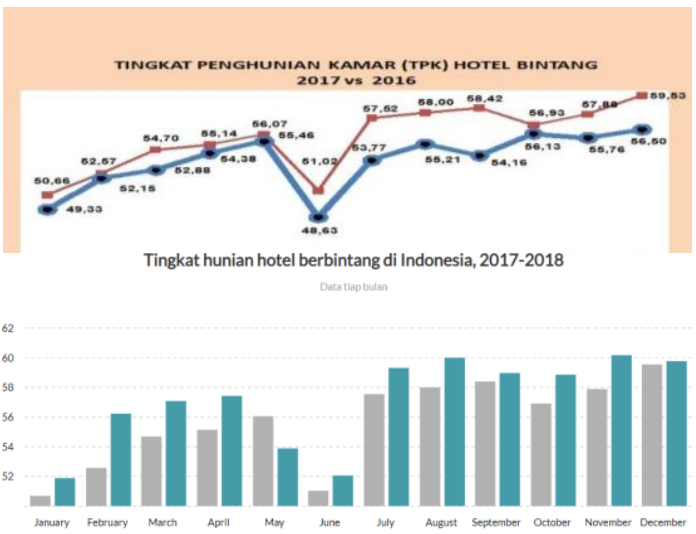

Gambar 1. Tingkat Penghunian Kamar (TPK) Hotel Bintang 2017 vs 2018

Sumber: (Badan Pusat Statistik, 2019)

Dari gambar di atas, bisa didefinisikan bahwa terdapat kenaikan tingkatpenghunian kamar secara umum sedang dalam setiap bulannya di setiap tahunnya. Bahkan di tahun 2018 sampai menyentuh titik tertinggi, yaitu 60\% (Pusat Data dan Sistem Informasi, 2018). Gambar 1.1 mencatatkan bahwa tahun 2017 mendapatkan fluktuasi yang cukup signifikan dibandingkan 2016, dan dirasakan di tahun 2016-2017 didapatkan rata-rata persentasekenaikan di setiap bulan mencapai $1-7 \%$. Kemudian antara 2017-2018 didapatkan persentase kenaikan di setiap bulan mencapai $1-6 \%$ perbandingan rata-rata. Sehingga menjadikan hotel di Indonesia memiliki jumlah yang tinggi tiap tahunnya dan menghasilkan fluktuasi yang baik bagi perekonomian pariwisata di Indonesia.

Tabel 1. Persaingan Tingkat Hunian Kamar (Occupancy) di saingan hotel Santika Premiere Slipi, Jakarta Sumber: S\&M, Diakses: 04/07/2021

\begin{tabular}{|c|c|c|c|c|c|c|}
\hline \multicolumn{5}{|c|}{ Desember 2020} & Occ & RREV \\
\hline 1 & IBIS SLIPI & $021-29205999$ & 143 & 129 & $90,21 \%$ & $82,634,309$ \\
\hline 2 & $\begin{array}{l}\text { MENARA } \\
\text { PENINSULA }\end{array}$ & 021-299 15999 & 150 & 120 & $80,00 \%$ & $84,495,842$ \\
\hline 3 & Hotel Ciputra & 02129667766 & 134 & 103 & $76,87 \%$ & $52,815,619$ \\
\hline 4 & $\begin{array}{l}\text { Menara Twin } \\
\text { Plaza }\end{array}$ & $021-29404955$ & 132 & 115 & $87,12 \%$ & $93,396,905$ \\
\hline 5 & $\begin{array}{l}\text { Aston Kartika } \\
\text { Grogol }\end{array}$ & $021-5982201$ & 243 & 156 & $64,20 \%$ & $53,906,268$ \\
\hline
\end{tabular}

Masalah yang berkaitan dengan proses keputusan pembelian di Hotel Santika Slipi yang berdasarkan hasil survey dan wawancara dengan salah satu karyawan Hotel, yaitu kurangnya informasi yang diperoleh calon konsumenii tentang Hotel. Setelah dilakukan pengamatan awal, permasalahan di atas salah satunya disebabkan oleh kurangnya bauran promosi yang dilakukan. Hal ini ditunjukan oleh beberapa indikasi sebagai berikut:

1. Iklan yang dilakukan Hotel masih belum sepenuhnya efektif,

2. Promosi penjualan yang dilakukan kurang gencar,

3. Publisitas dan hubungan masyarakat masih kurang digali potensinya.

4. Kompetisi bisnis perhotelan tak hanya sekedar kompetisi dari perspektif akomodasi wujud, contohnya kamar, tetapi salah satu taktik juga adalah aspek promosi yang efektif dalam menghadapi persaingan yang ada di dunia perhotelan. Promosi ialah inti pemasaran yang menjadi unsur krusial, yang bisa disimpulkan bahwa sebesar apapun kegunaan suatu produk atau jasa, bila konsumen tidak 
mengenal product yang akan ditawarkan maka kegunaannya tidak akan diketahui oleh konsumen tersebut (Prawira \&Pangestuti, 2019).

Alasan keputusan menginap dibilang kurang meningkat dengan pengaruh bauran promosi dari penelitian sebelumnya, yaitu iklan yang dilakukan belum menunjukkan efektivitas atau pengaruh (advertising) kurang gencarnya promos penjualan (sales promotion), serta publisitas dan hubungan masyarakat tidak dilakukan dengan baik (customer relationship) (Raharta, 2017).

Berdasarkan latar belakang yang sudah dijabarkan, dapat dibuat rumusan masalah, yaitu:

1. Bagaimana pengaruh periklanan (advertising) terhadap keputusan menginap?

2. Bagaimana promosipenjualan (salespromotion) keputusan menginap?

3. Bagaimana pengaruh penjualan pribadi (personal selling) terhadap keputusan menginap?

Bagaimana pengaruh hubungan masyarakat (public relations) terhadap keputusan menginap?

Bagaimana pengaruh pemasaran langsung(direct marketing) terhadap keputusan menginap?

Bagaimana pengaruh bauran promosi terhadap keputusan menginap

Rerangka pemikiran dibuat agar memperjelas konsep pemikiran yang hendak dikaji dan disampaikan.
Kerangka pemikiran akan peneliti jabarkan sebagai berikut:

Gambar 2. Rerangka Pemikiran Sumber: (Kotler \& Armstrong, 2012432)

\section{METODE PENELITIAN}

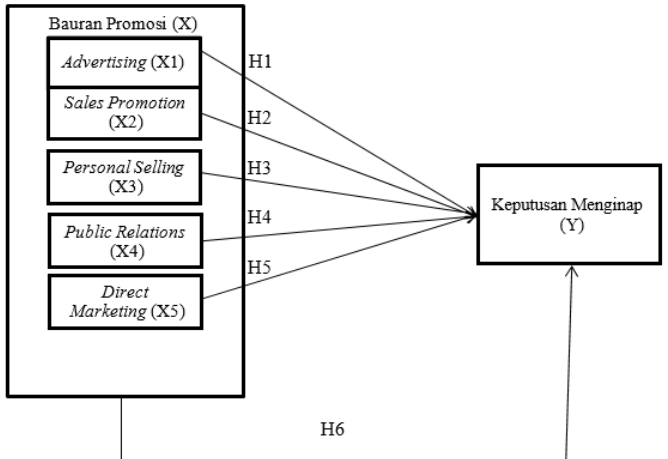

Penelitian secara umum diartikan sebagai suatu proses pengumpulan dan analisis data yang dilakukan secara sistematis dan logis untuk mencapai tujuan tertentu (Winarni, 2018, p. 2).

Penelitian adalah proses ilmiah yang mencakup sifat formal karena terikat dengan aturan, urutan maupun cara penyajian agar memperoleh hasil yang diakui, serta bermanfaat bagi kehiduapan manusia intensifmenerapkan ketelitian dan ketepatan dalam melakukan proses penelitian agar memperoleh hasil yang dapat dipertanggungjawabkan, memecahkan problem melalui hubungan sebab akibat, dapat diulang kembali dengan cara dan hasil yang sama (Winarni, 2018, p. 3).

Metode penelitian kuantitatif, Penelitian kuantitatif dapat diartikan sebagai metode penelitian yang berlandaskan pada filsafat positivisme yang digunakan untuk meneliti pada populasi atau sampel tertentu. Pengumpulan data menggunakan 
instrument penelitian dan analisis data bersifatkuantitatif/statistic dengan tujuan menguji hipotesis yang telah ditetapkan (Winarni, 2018, p. 24).

Pengumpulan data yang akan menentukan berhasil atau tidaknya pada penelitian adalah pengertian dari metode pengumpulan data (Syafnidawaty, 2020). Terdapat 2 sumber pada metode pengumpulan data, yaitu :

Data Sekunder: data yang didapat dari sumber kedua atau sumber sekunder, seperti lembaga atau institusi.

Data Primer: data yang didapat atau diperoleh secara langsung dari sumber data melalaui penelitian atau objek penelitian.

Pada penelitian ini, peneliti menggunakan data primer atau data yang didapat secara langsung dari sumber data melalui penelitian atau objek penelitian (wawancara, observasi, atau kuesioner). Terdapat berbagai teknik pengumpulan data menurut (Winarni, 2018, p. 64), yaitu :

Tes adalah rangkaian atau latihan yang digunakan untuk mengukur keterampilan, pengetahuan, sikap, kecerdasan, kemampuan atau bakat yang dimiliki oleh individu atau kelompok. Beberapa macam tes yang biasa digunakan dalam penilaian, yaitu tes kepribadian, tes bakat, tes intelegensi, tes minat, tes prestasi, dan tes sikap.

Wawancara adalah metode pengumpulan data yang membutuhkan komunikasi langsung antara peneliti dan subjek atau responden. Dalam wawancara, tanya jawab sepihak biasanya dilakukan secara sistematis dan berdasarkan tujuan penelitian.

Kuesioner adalah alat untuk mengumpulkan data berupa daftar pertanyaan yang diajukan kepada responden untuk dijawab secara tertulis.

Observasi adalah metode pengumpulan data yang menggunakan pengamatan terhadap objek penelitian. Observasi dapat dilakukan secara langsung dan tidak langsung.

Populasi menurut (Fraenkel \& Wallen, 1990) dalam buku (Winarni, 2018, p. 38) adalah kelompok yang menarik peneliti, dimana kelompok tersebut digunakan peneliti sebagai objek untuk menggeneralisasi hasil penelitian. Populasi juga didefinisikan sebagai himpunan yang terdiri dari manusia, hewan, tumbuhan, dan benda-benda yang memiliki ciri- ciri yang sama.

Populasi dalam penelitian yang akan dilakukan peneliti adalah rata-rata tamu hotel yang pernah datang ke Hotel Santika Slipi Jakarta dari januari-maret 2021 berjumlah 860 orang yang dapat dilihat dari Januari 2021: 1.031 orang, Februari 2021: 953 orang, Maret 2021: 598 orang. 


$$
n=\frac{N}{1+\left(N \times e^{2}\right)}
$$

11. 659

$$
\boldsymbol{n}=\frac{1+\left(11.659 \times(5 \%)^{2}\right)}{1+65}
$$

$$
\begin{aligned}
& n=\frac{11.659}{1+\left(11.659 \times(0,05)^{2}\right)} \\
& n=\frac{11.659}{1+(11.659 \times 0,0025)} \\
& n=\frac{11.659}{30,1475}=386,731901
\end{aligned}
$$

Sampel yang digunakan dalam penelitian ini adalah Perhitungan jumlah sampel menggunakan rumus slovin,

Dalam menguji dan memudahkan analisa data diperlukan bantuan program pengolahan data yaitu IBM SPSS Statistic 25.0 yang merupakan teknik pengukuran untu menguji pernyataan yang diberikan valid dalam analisis uji validitas dan uji reliabilitas.

Validitas adalah sebuah indikator yang memaparkan bahwa suatu tolak ukur untuk mengukur instrument yangharusdiukur.Validitas. memperlihat kan tingkat presisi data sebenarnya untuk menunjukan objek data yang dikumpulkan peneliti. Instrumen tersebut bisa digunakan untuk mengukur apakah instrumen digunakan peneliti valid, agar dapat diketahui semua pernyataan di kuesione yang dibuat peneliti tersebut itu sah (valid), sehingga harus tes dengan percobaan antara nilai setiap poin-poin pertanyaan dengan nilai total yang terdapat dalam kuesioner. Berlandaskan (Sugiyono, 2017) mengemukakan adanya syarat dalam uji validitas yang harus dipenuhi ialah, yakni:
Jika koefiseinsi $\mathrm{r}$ hitung $>\mathrm{r}$ table maka pernyataan tersebut dinyatakan valid Jika koefisiensi korelasi $\mathrm{r}$ hitung $<\mathrm{r}$ tabel maka pernyataan tersebut dinyatakan tidak valid.

Skala Likert Adalah skala agar mengetahui pandangan responden tentang pengukuran tingkat kesetujuan atau tidak setuju terhadap pernyataan yang terkait dengan objek yang terdapat dalam sebuah penelitian. Biasanya skala ini menggunakan 1-5 penilaian.

Tabel 2. Penilaian Skala

\section{Likert}

\begin{tabular}{|l|c|}
\hline \multicolumn{1}{|c|}{ Keterangan } & Penilaian \\
\hline Sangat Setuju (SS) & 5 \\
\hline Setuju (S) & 4 \\
\hline Ragu (R) & 3 \\
\hline Tidak Setuju (TS) & 2 \\
\hline Sangat Tidak Setuju (STS) & 1 \\
\hline
\end{tabular}

Pengukuran setiap variabel pada penelitian ini menggunakan skala instrumen yang dipakai dalam penelitian ini adalah menggunakan Skala Likert dengan kisaran $1-5$.

Dalam penelitian ini akan dibagikan 386 responden kepada para calon pengunjung atau responden yang berjumlah 273 orang secara acak dalam bentuk online (Google Forms).

Terdapat teknik korelasi yang dapat dipakai untuk uji validitas, untuk dapat mencari korelasinya, peneliti menggunakan rumus Pearson Product Moment atau teknik korelasi product moment yang memiliki fungsi untuk mengetahui relevansi setiap pertanyaan apakah signifikan atau tidak.

Korelasi product moment untuk uji hipotesis nihil tentang hubungan antara dua variable (variabel $\mathrm{X}$ dan $\mathrm{Y}$ ). 
Uji reliabilitas digunakan untuk memperoleh hasil penelitian yang valid dan reliabel serta digunakan untuk mengukur berkali-kali untuk menghasilkan data atau konsistensi yang sama (Sugiyono, 2017, p. 199). Uji reliabilitas dilakukan untuk mengetahui seberapa jauh hasil pengukuran tetap konsisten apabila dilakukan dua kali pengukuran atau lebih terhadaptanda yang sama dengan menggunakan alat ukur yang sama. Untuk melihat reliabilitas dari masing-masing instrumen yang digunakan, penulis menggunakan teknik Cronbach Alpha ( $\alpha)$ dengan menggunakan software IBM SPSS Statistics versi 25.0for windows 32-bit. Suatu instrumen dikatakan reliabel jika nilai Cronbach Alpha lebih besar dari 0,6

Uji Normalitas Menurut (Ghozali, 2016) uji normalitas dilakukan untuk menguji apakah dalam suatu model regresi variabel bebas dan variabel terikat atau keduanya berdistribusi normal atau tidaknormal. Jika suatu variabel tidak berdistribusi normal, maka hasil uji statistik akan menurun. Uji normalitas data dapat dilakukan dengan menggunakan uji Kolmogorov-smirnov One Sample, dengan syarat jika nilai signifikansi di atas 5\% atau 0,05 maka data berdistribusi normal. Sedangkan jika hasil uji Kolmogorov-smirnov One Sample menghasilkan nilai signifikan dibawah 5\%atau 0,05 maka data tidak berdistribusi normal

Analisis regresi linier berganda bertujuan untuk mengetahui dan memprediksi apakah variabel independen (X) berpengaruh terhadap variabel dependen (Y) dan seberapa besar pengaruhnya ketiga variabel bebas terhadap variabel terikat (Y)
Uji koefisien ialah uji yang bertujuan untuk mengukur seberapa jauh kemampuan model dalam menerangkan variasi-variabel dependen. Nilai koefisien determinasi ialah antara nol dan satu. Nilai $\mathrm{R}^{2}$ yang kecil menandakan bahwa kemampuan variabel-variabel independen dalam mengungkapkan variabel dependen sangatlah terbatas. Klasifikasi koefisien korelasi tanpa memperhatikan arah ialah sebagai berikut (Ghozali, 2016): Menurut (Ghozali, 2016, p. 171) Uji pengaruh simultan digunakan untuk mengetahui apakah variabel independen secara bersama-sama atau simultan mempengaruhi variabel dependen. Uji pengaruh simultan (Uji $F)$ dikenal dengan Uji Anova. Uji statistik F pada analisis data penelitian ini menggunakan standar kepercayaan 95\% ( $\alpha=0,05$ $(5 \%)$ ). Jika tingkat signifikansi lebih besar 0,05 maka disimpulkan bahwa $\mathrm{H} 0$ diterima, sebaliknya $\mathrm{H} 1$ ditolak.

Jika tingkat signifikansi lebih kecil 0,05 maka bisa disimpulkan bahwa $\mathrm{H} 0$ ditolak, sebaliknya $\mathrm{H} 1$ diterima.

*dengan memakai nilai probabilitas signifikansi

Rumusan hipotesis uji $\mathrm{F}$ ialah sebagai berikut:

H0 : terbukti tidak terdapat pengaruh secara simultan bauranpromosi terhadap keputusan menginap.

H1 : terbukti bahwa terdapat pengaruh secara simultan bauran promosi terhadap keputusan menginap.

Menurut (Ghozali, 2016, p. 171) Uji parsial digunakan untuk mengetahui pengaruh masing-masing variabel independen terhadap variabel dependen. 
Uji Parsial pada analisis data penelitian ini menggunakan derajat signifikansi yaitu 0,05 . Uji t dalam penelitian ini akan dilakukan dengan menggunakan bantuan program SPSS 25 for windows 32-bit yang disajikan pada tabel Coefficient.

\section{HASIL DAN PEMBAHASAN}

\section{Tabel 3. Karakteristik Responden Menurut Jenis Kelamin}

\begin{tabular}{|l|l|l|l|}
\hline \multicolumn{1}{|c|}{ Pekerjaan } & Frekuensi & Persentase & Persentase Valid \\
\hline Lelaki & 131 & $47,6 \%$ & $47,6 \%$ \\
\hline Perempuan & 142 & $52,4 \%$ & $52,4 \%$ \\
\hline Total & 273 & $100 \%$ & $100 \%$ \\
\hline
\end{tabular}

Berdasarkan tabel 6 di atas bisa dinyatakan bahwa dari 273 responden yang telah mengisi kuesioner, karakteristik responden lelaki mencapai 131 responden dengan persentase 47,6\%, serta karakteristik responden perempuan mencapai 142 responden dengan persentase $52,4 \%$. Sehingga bisa disimpulkan bahwa karakteristik responden perempuan lebih dominan berkunjung ke hotel Santika Premiere Slipi dibandingkan responden lelaki.

\section{Tabel 4. Karakteristik Responden Menurut Usia}

\begin{tabular}{|l|l|l|l|}
\hline Pekerjaan & Frekuensi & Persentase & Persentase Valid \\
\hline$<20$ tahun & 43 & $15 \%$ & $15 \%$ \\
\hline $21-39$ & 90 & $33 \%$ & $33 \%$ \\
\hline $40-55$ & 107 & $39 \%$ & $39 \%$ \\
\hline$>56$ & 33 & $12 \%$ & $12 \%$ \\
\hline Total & 273 & $100 \%$ & $100 \%$ \\
\hline
\end{tabular}

Menurut tabel 7 di atas menyatakan bahwa dari 273 respondenyang telah mengisi kuesioner, karakteristik yang lebih muda dari 21 tahun mencapai 43 responden dengan persentase $15 \%$, karakteristik 20-39 tahun mencapai 90 responden dengan persentase $33 \%$, karakteristik 40-55 tahun mencapai 107 responden dengan persentase $39 \%$, kemudian karakteristik yang lebih tua dari 56 tahun mencapai 33 responden dengan persentase 12\%. Dari tabel tersebut bisa disimpulkan bahwa karakteristik menurut usia yang paling dominan berkunjung adalah usia 40-55 tahun dibandingkan karakteristik menurut usia lainnya.

\section{Tabel 5. Karakteristik Responden} Menurut Pekerjaan

\begin{tabular}{|l|c|c|c|}
\hline \multicolumn{1}{|c|}{ Pekerjaan } & Frekuensi & Persentase & Persentase Valid \\
\hline Wirausaha & 25 & $9 \%$ & $9 \%$ \\
\hline Karyawan & 86 & $31 \%$ & $31 \%$ \\
\hline PNS & 150 & $54 \%$ & $54 \%$ \\
\hline Lainnya & 12 & $4 \%$ & $4 \%$ \\
\hline Total & 273 & $100 \%$ & $100 \%$ \\
\hline
\end{tabular}

Dari Tabel 8 yang memiliki jumlah 273 responden, karakteristik wirausaha mencapai 25 responden dengan persentase $9 \%$, karakterstik karyawan mencapai 86 responden dengan persentase $31 \%$, karakteristik pegawai negeri sipil (PNS) mencapai 150 responden dengan persentase $54 \%$, dan karakteristik lainnya mencakup mahasiswa, freelancer, dan ibu rumah tangga mencapai 12 responden dengan persentase 4\%. Menurut tabel diatas bisa disimpulkan bahwa karakteristik menurut pekerjaan pegawai negeri sipil lebih dominan berkunjung dibandingkan karakteristik menurut pekerjaan lainnya

Tabel 6. Sampel Advertising Tabel Y11

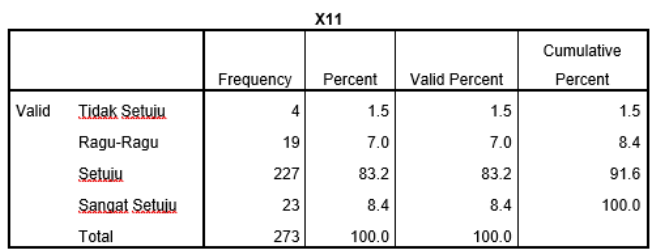

Berdasarkan tabel di atas, dapat dinyatakan bahwa sebanyak 227 atau $83.2 \%$ menyatakan setuju dan hanya 4 responden atau $1.5 \%$ yang menyatakan tidak setuju. 
Tabel X12

\begin{tabular}{|c|c|c|c|c|c|}
\hline & & Frequency & Percent & Valid Percent & $\begin{array}{c}\text { Cumulative } \\
\text { Percent }\end{array}$ \\
\hline \multirow[t]{6}{*}{ Valid } & Sangat Tidak Setuiu & 10 & 3.7 & 3.7 & 3.7 \\
\hline & Iidak Setuju & 19 & 7.0 & 7.0 & 10.6 \\
\hline & Ragu-Ragu & 45 & 16.5 & 16.5 & 27.1 \\
\hline & Setuin & 187 & 68.5 & 68.5 & 95.6 \\
\hline & Sanaat Setuiu & 12 & 4.4 & 4.4 & 100.0 \\
\hline & Total & 273 & 100.0 & 100.0 & \\
\hline
\end{tabular}

Berdasarkan tabel di atas, dapat dinyatakan bahwa sebanyak 187 atau $68.5 \%$ menyatakan setuju dan hanya 10 responden atau $3.7 \%$ yang menyatakan sangat tidak setuju.

Tabel X13

\begin{tabular}{|l|r|r|r|r|}
\hline & & & & \multicolumn{1}{c|}{$\begin{array}{c}\text { Cumulative } \\
\text { Percent }\end{array}$} \\
\hline Valid & Frequency & Percent & Valid Percent & Sangat Tidak Setwiu \\
Tidak Setuju & 10 & 3.7 & 3.7 & 3.7 \\
& 19 & 7.0 & 7.0 & 10.6 \\
Ragu-Ragu & 45 & 16.5 & 16.5 & 27.1 \\
Setuiu & 176 & 58.5 & 68.5 & 95.6 \\
Sangat Setuiu & 12 & 4.4 & 4.4 & 100.0 \\
Total & 273 & 100.0 & 100.0 & \\
\hline
\end{tabular}

Berdasarkan tabel di atas, dapat dinyatakan bahwa sebanyak 176 atau $58.5 \%$ menyatakan setuju dan hanya 10 responden atau $3.7 \%$ yang menyatakan sangat tidak setuju.

Tabel X14

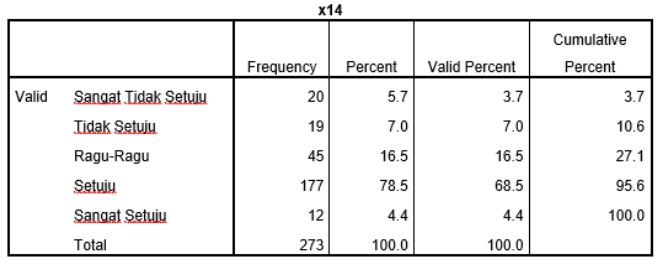

Berdasarkan tabel di atas, dapat dinyatakan bahwa sebanyak 177 atau $78.5 \%$ menyatakan setuju dan hanya 20 responden atau $5.7 \%$ yang menyatakan sangat tidak setuju.

Tabel 7. Sampel Sales Promotion Tabel X21

\begin{tabular}{|c|c|c|c|c|c|}
\hline \multicolumn{6}{|c|}{ X21 } \\
\hline & & Frequency & Percent & Valid Percent & $\begin{array}{c}\text { Cumulative } \\
\text { Percent }\end{array}$ \\
\hline \multirow[t]{6}{*}{ Valid } & Sangat Tidak Setuiy & 7 & 2.6 & 2.6 & 2.6 \\
\hline & Jidak Setuju & 17 & 6.2 & 6.2 & 8.8 \\
\hline & Ragu-Ragu & 54 & 19.8 & 19.8 & 28.6 \\
\hline & Setuin & 185 & 67.8 & 67.8 & 96.3 \\
\hline & Sangat Setuiy & 10 & 3.7 & 3.7 & 100.0 \\
\hline & Total & 273 & 100.0 & 100.0 & \\
\hline
\end{tabular}

Berdasarkan tabel di atas, dapat dinyatakan bahwa sebanyak 185 atau $67.8 \%$ menyatakan setuju dan hanya 7 responden atau $2.6 \%$ yang menyatakan sangat tidak setuju.

Tabel X22

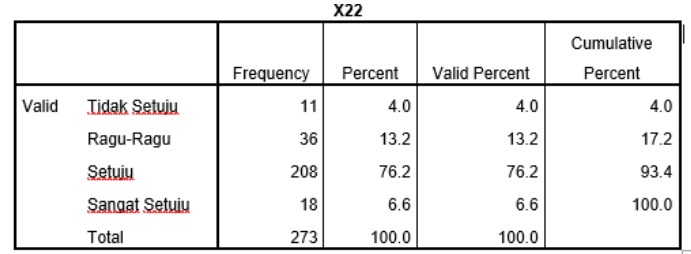

Berdasarkan tabel di atas, dapat dinyatakan bahwa sebanyak 208 atau $76.2 \%$ menyatakan setuju dan hanya 11 responden atau $4.0 \%$ yang menyatakan tidak setuju.

Tabel 8. Sampel Personal Selling Tabel X31

\begin{tabular}{|c|c|c|c|c|c|}
\hline & & Frequency & Percent & Valid Percent & $\begin{array}{l}\text { Percent } \\
\end{array}$ \\
\hline \multirow[t]{6}{*}{ Valid } & Sancat Tidak Setuiu & 4 & 1.5 & 1.5 & 1.5 \\
\hline & Tidak Setuju & 19 & 7.0 & 7.0 & 8.4 \\
\hline & Ragu-Ragu & 38 & 13.9 & 13.9 & 22.3 \\
\hline & Setuix & 196 & 71.8 & 71.8 & 94.1 \\
\hline & Sancat Setuiu & 16 & 5.9 & 5.9 & 100.0 \\
\hline & Total & 273 & 100.0 & 100.0 & \\
\hline
\end{tabular}

Berdasarkan tabel di atas, dapat dinyatakan bahwa sebanyak 196 atau $71.8 \%$ menyatakan setuju dan hanya 4 responden atau $1.5 \%$ yang menyatakan sangat tidak setuju.

Tabel X32 


\begin{tabular}{|c|c|c|c|c|c|}
\hline \multicolumn{6}{|c|}{$\mathrm{x} 32$} \\
\hline & & Frequency & Percent & Valid Percent & $\begin{array}{c}\text { Cumulative } \\
\text { Percent }\end{array}$ \\
\hline \multirow[t]{5}{*}{ Valid } & Tidak Setuju & 3 & 1.1 & 1.1 & 1.1 \\
\hline & Ragu-Ragu & 25 & 9.2 & 9.2 & 10.3 \\
\hline & Setuin & 221 & 81.0 & 81.0 & 91.2 \\
\hline & Sangat Setuiu & 24 & 8.8 & 8.8 & 100.0 \\
\hline & Total & 273 & 100.0 & 100.0 & \\
\hline
\end{tabular}

Berdasarkan tabel di atas, dapat dinyatakan bahwa sebanyak 221 atau $81.0 \%$ menyatakan setuju dan hanya 3 responden atau $1.1 \%$ yang menyatakan sangat tidak setuju.

Tabel X33

\begin{tabular}{|c|c|c|c|c|c|}
\hline & & Frequency & Percent & Valid Percent & $\begin{array}{c}\text { Cumulative } \\
\text { Percent }\end{array}$ \\
\hline \multirow[t]{6}{*}{ Valid } & Sangat Tidak Setuiu & 10 & 3.7 & 3.7 & 3.7 \\
\hline & Jidak Setuju & 19 & 7.0 & 7.0 & 10.6 \\
\hline & Ragu-Ragu & 45 & 16.5 & 16.5 & 27.1 \\
\hline & Setuin & 187 & 68.5 & 68.5 & 95.6 \\
\hline & Sanaat Setuiu & 12 & 4.4 & 4.4 & 100.0 \\
\hline & Total & 273 & 100.0 & 100.0 & \\
\hline
\end{tabular}

Berdasarkan tabel di atas, dapat dinyatakan bahwa sebanyak 187 atau $68.5 \%$ menyatakan setuju dan hanya 10 responden atau $3.7 \%$ yang menyatakan sangat tidak setuju.

\section{Tabel 9. Sampel Public Relations}

Tabel X41

\begin{tabular}{|c|c|c|c|c|c|}
\hline & & Frequency & Percent & Valid Percent & $\begin{array}{c}\text { Cumulative } \\
\text { Percent }\end{array}$ \\
\hline \multirow[t]{6}{*}{ Valid } & Sancat Tidak Setuiu & 10 & 3.7 & 3.7 & 3.7 \\
\hline & Tidak Setuju & 19 & 7.0 & 7.0 & 10.6 \\
\hline & Ragu-Ragu & 45 & 16.5 & 16.5 & 27.1 \\
\hline & Setuiu & 187 & 68.5 & 68.5 & 95.6 \\
\hline & Sangat Setuiu & 12 & 4.4 & 4.4 & 100.0 \\
\hline & Total & 273 & 100.0 & 100.0 & \\
\hline
\end{tabular}

Berdasarkan tabel di atas, dapat dinyatakan bahwa sebanyak 187 atau $68.5 \%$ menyatakan setuju dan hanya 10 responden atau $3.7 \%$ yang menyatakan sangat tidak setuju.
Tabel X42

\begin{tabular}{|c|c|c|c|c|c|}
\hline \multicolumn{6}{|c|}{$\times 42$} \\
\hline & & Frequency & Percent & Valid Percent & $\begin{array}{l}\text { Cumulative } \\
\text { Percent }\end{array}$ \\
\hline \multirow[t]{6}{*}{ Valid } & Sanaat Tidak Setuiu & 9 & 2.5 & 2.5 & 3.7 \\
\hline & Tidak Setuju & 10 & 8.2 & 8.2 & 10.6 \\
\hline & Ragu-Ragu & 5 & 11.5 & 11 & 27.1 \\
\hline & Setuir & 180 & 65.2 & 65.2 & 95.6 \\
\hline & Sangat Setuiu & 10 & 1.4 & 1.4 & 100.0 \\
\hline & Total & 273 & 100.0 & 100.0 & \\
\hline
\end{tabular}

Berdasarkan tabel di atas, dapat dinyatakan bahwa sebanyak 180 atau $65.2 \%$ menyatakan setuju dan hanya 9 responden atau $2.5 \%$ yang menyatakan sangat tidak setuju.

Tabel X43

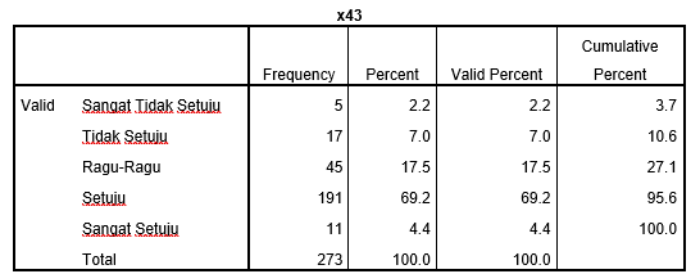

Berdasarkan tabel di atas, dapat dinyatakan bahwa sebanyak 191 atau $69.2 \%$ menyatakan setuju dan hanya 5 responden atau $2.2 \%$ yang menyatakan sangat tidak setuju.

Tabel 10. Sampel Direct Marketing Tabel X51

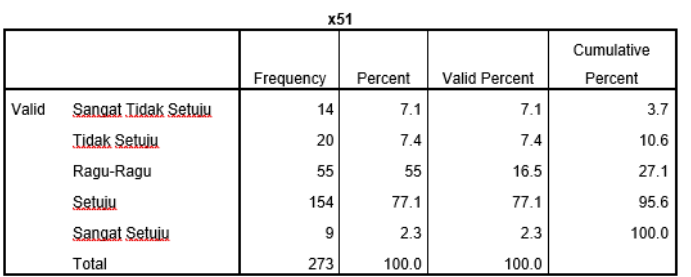

Berdasarkan tabel di atas, dapat dinyatakan bahwa sebanyak 154 atau $77.1 \%$ menyatakan setuju dan hanya 14 responden atau $7.1 \%$ yang menyatakan sangat tidak setuju. 
Tabel X52

\begin{tabular}{|c|c|c|c|c|c|}
\hline & Frequency & Percent & Valid Percent & $\begin{array}{c}\text { Cumulative } \\
\text { Percent }\end{array}$ \\
\hline Valid & Sancat Tidak Setuiu & 22 & 6.9 & 6.9 & 3.7 \\
\hline & Tidak Setwiu & 19 & 7.0 & 7.0 & 10.6 \\
\hline & Ragu-Ragu & 45 & 16.5 & 16.5 & 27.1 \\
\hline & Setuiu & 198 & 68.5 & 68.5 & 95.6 \\
\hline & Sangat Setuiu & 12 & 4.4 & 4.4 & 100.0 \\
\hline & Total & 273 & 100.0 & 100.0 & \\
\hline
\end{tabular}

Berdasarkan tabel di atas, dapat dinyatakan bahwa sebanyak 198 atau $68.1 \%$ menyatakan setuju dan hanya 22 responden atau $6.9 \%$ yang menyatakan sangat tidak setuju

\section{Tabel 11. Sampel Keputusan Menginap \\ Tabel Y1}

\begin{tabular}{|c|c|c|c|c|c|}
\hline & & Frequency & Percent & Valid Percent & $\begin{array}{c}\text { Cumulative } \\
\text { Percent } \\
\end{array}$ \\
\hline \multirow[t]{5}{*}{ Valid } & Tidak Setuju & 12 & 4.4 & 4.4 & 4.4 \\
\hline & Ragu-Ragu & 38 & 13.9 & 13.9 & 18.3 \\
\hline & Setuiu & 207 & 75.8 & 75.8 & 94.1 \\
\hline & Sancat Setwiu & 16 & 5.9 & 5.9 & 100.0 \\
\hline & Total & 273 & 100.0 & 100.0 & \\
\hline
\end{tabular}

Berdasarkan tabel di atas, dapat dinyatakan bahwa sebanyak 207 atau $75.8 \%$ menyatakan setuju dan hanya 12 responden atau $4.4 \%$ yang menyatakan sangat tidak setuju

\section{Tabel Y2}

\begin{tabular}{|c|c|c|c|c|c|}
\hline & & Frequency & Percent & Valid Percent & $\begin{array}{c}\text { Cumulative } \\
\text { Percent }\end{array}$ \\
\hline \multirow[t]{6}{*}{ Valid } & Sangat Tidak Setuiu & 5 & 1.8 & 1.8 & 1.8 \\
\hline & Jidak Setuju & 16 & 5.9 & 5.9 & 7.7 \\
\hline & Ragu-Ragu & 39 & 14.3 & 14.3 & 22.0 \\
\hline & Setuix & 193 & 70.7 & 70.7 & 92.7 \\
\hline & Sanaat Setuiu & 20 & 7.3 & 7.3 & 100.0 \\
\hline & Total & 273 & 100.0 & 100.0 & \\
\hline
\end{tabular}

Berdasarkan tabel di atas, dapat dinyatakan bahwa sebanyak 193 atau $70.7 \%$ menyatakan setuju dan hanya 5 responden atau $1.8 \%$ yang menyatakan sangat tidak setuju.
Tabel Y3

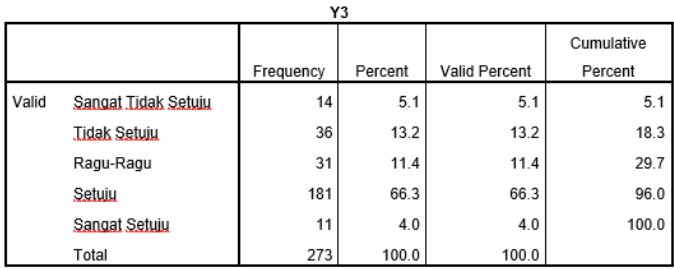

Berdasarkan tabel di atas, dapat dinyatakan bahwa sebanyak 181 atau $66.3 \%$ menyatakan setuju dan hanya 14 responden atau $5.1 \%$ yang menyatakan sangat tidak setuju.

Tabel Y4

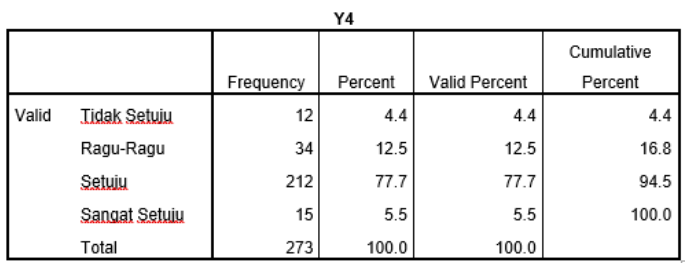

Berdasarkan tabel di atas, dapat dinyatakan bahwa sebanyak 212 atau $77.7 \%$ menyatakan setuju dan hanya 12 responden atau $4.4 \%$ yang menyatakan sangat tidak setuju.

Tabel Y5

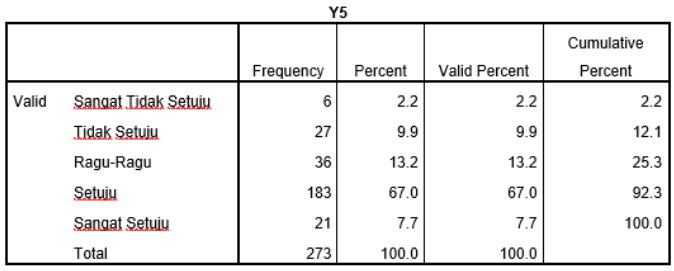

Berdasarkan tabel di atas, dapat dinyatakan bahwa sebanyak 163 atau $67.0 \%$ menyatakan setuju dan hanya 6 responden atau $2.2 \%$ yang menyatakan sangat tidak setuju.

Tabel 12. Hasil Uji Validitas X 

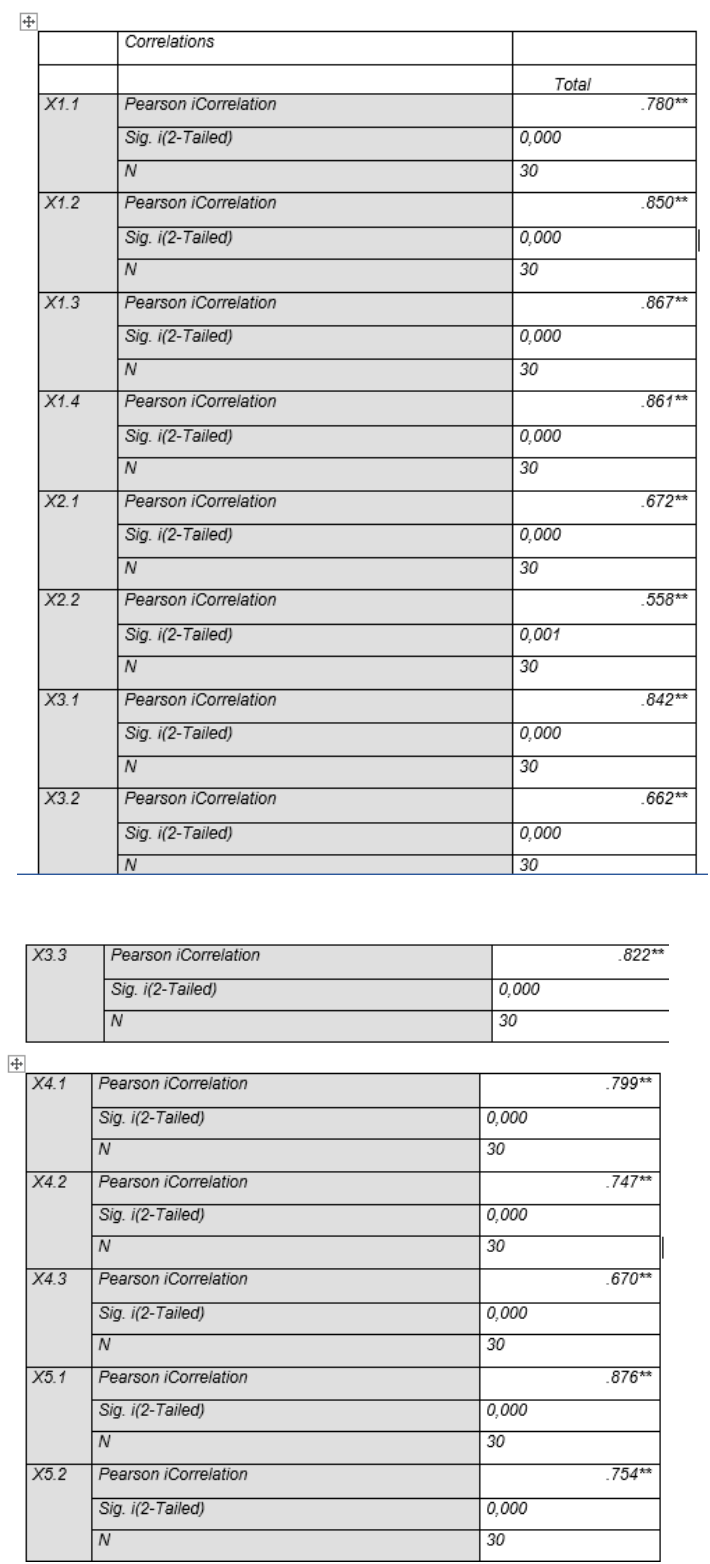

Dari $r$ tabel dengan 30 responden, didapati nilai $\mathrm{r}$ tabel, yaitu 0,361 . Untuk mengetahui hasil valid atau tidaknya dilihat dari $r_{\text {tabel }}<r_{\text {hitung. Dari semua }}$ variabel $\mathrm{X}$ yang ditunjukan, semua variabel dikatakan positif karena lebih besar daripada $\mathrm{r}_{\text {tabel. }}$. Bisa dilihat dari tabel di atas yang bisadisebut $\mathrm{r}_{\text {hitung }}=$ Pearson Correlation. Semua variabel $\mathrm{X}$ di atas dikatakan valid
Tabel 13. Hasil Uji Validitas variabel

\begin{tabular}{|l|l|l|}
\hline & Correlations & \multicolumn{2}{|c|}{} \\
\hline & & \multicolumn{2}{|c|}{ Total } \\
\hline Y1 & Pearson iCorrelation & \multicolumn{2}{|c|}{$.846^{* *}$} \\
\cline { 2 - 4 } & Sig. i(2-Tailed $)$ & 0,000 \\
\cline { 2 - 4 } & $N$ & 30 \\
\hline Y2 & Pearson iCorrelation & \multicolumn{2}{|c}{$.828^{* *}$} \\
\hline
\end{tabular}

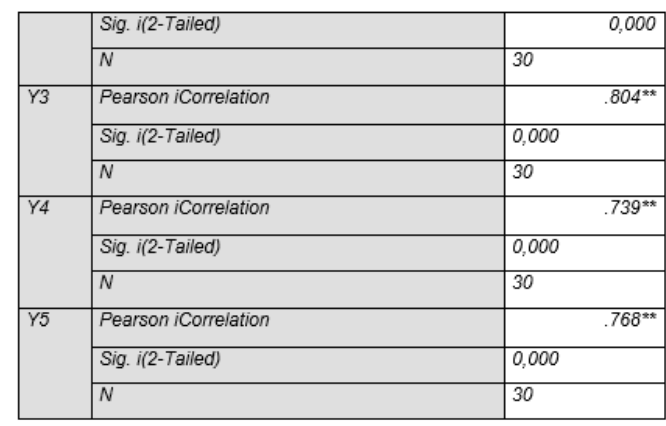

$\mathbf{Y}$
Dari $r$ tabel dengan 30 responden, didapati nilai $r$ tabel, yaitu 0,361 . Untuk mengetahui hasil valid atau tidaknya dilihat dari $\mathrm{r}_{\text {tabel }}<\mathrm{r}_{\text {hitung. Dari }}$ semua variabel $\mathrm{Y}$ yang ditunjukan, semua variabel dikatakan positif karena lebih besar daripada $r$ tabel. Bisa dilihat dari tabel di atas yang bisa disebut $r_{\text {hitung }}=$ Pearson Correlation. Semua variabel Y di atas dikatakan valid

\section{Tabel 14. Hasil Uji Reliabilitas variabel X}

\section{Reliability Statistics}

彗

\begin{tabular}{l|l} 
Cronbach Alpha & N of items \\
\hline .946 & 14
\end{tabular}

Hasil yang diperoleh dapat dilihat bahwa nilai Cronbach Alpha pada variabel $\mathrm{X}$ adalah sebesar 0,946 yang lebih besar dari batas minimal 0,6. Sehingga dapat disimpulkan bahwa 
item pernyataan untuk mengukur variabel $\mathrm{X}$ dapat diandalkan

\section{Tabel 15. Hasil Uji Reliabilitas variabel $Y$}

\begin{tabular}{l|l}
$\begin{array}{l}\text { Reliability Statistics } \\
\text { Cronbach Alpha }\end{array}$ & N of items \\
\hline .922 & 5 \\
\hline
\end{tabular}

Hasil yang diperoleh dapat dilihat bahwa nilai Cronbach Alpha pada variabel $\mathrm{Y}$ adalah sebesar 0,922 yang lebih besar dari batas minimal 0,6. Sehingga dapat disimpulkan bahwa item pernyataan untuk mengukur variabel $\mathrm{Y}$ dapat diandalkan

\section{Tabel 16. Hasil Uji Multikolinearitas}

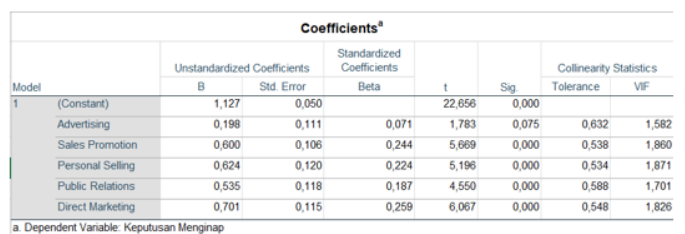

Uji ini dilakukan untuk mengetahui terdapat atau tidak terjadinya korelasi antara variabel bebas (Advertising, Sales Promotion, Promotion, Personal Selling, Public Relations, dan Direct Marketing) atau tidak terjadi multikolinearitas. Dengan membandingkan nilai tolerance dari perhitungan regresi berganda, jika nilai VIF lebih besar 10, maka dapat dikatakan bahwa variabel tersebut terjadi multikolinearitas.

Berdasarkan tabel 19, dapat dinyatakan bahwa untuk variabel bebas tidak terjadi multikolinearitas. Dan hasilnya dapat ditunjukan dari nilai VIF dari semua variabel bebas, yaitu: Advertising sebanyak 1,582, Sales Promotion sebanyak 1,860, Personal Selling sebanyak 1,871, Public Relations sebanyak 1,701, dan Direct Marketing sebanyak 1,826, dimana VIF lebih kecil

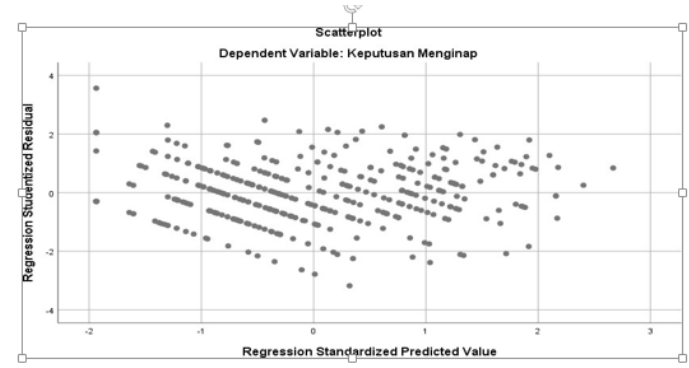

dari 10. Selain itu, dapat dilihat dari nilai tolerance dari semua variabel bebas nilainya lebih besar dari taraf 0,05 (tingkat kesalahan 5\%).

Gambar 2. Hasil Uji Heterokedastisitas

Metode ini digunakan untuk menguji terdapat atau tidaknya terjadi heterokedastisitas, yaitu uji grafik Scatterplot dengan menggunakan perangkat lunak SPSS 25.00 for windows 32-bit. Darihasil pengujian gambar 4.6, dapat dilihat bahwa tampilan diagram Scatterplot tidak membentuk pola tertentu dan menyebar secara acak sehingga dapat dinyatakan bahwa tidak terjadi heterokedastisitas dalam penelitian ini. Dapat disimpulkan bahwa ragam (varians) untuk variabel bebas adalah homogen (tidak terdapat heterokedastisitas).

\section{Tabel 17. Hasil Uji Autokorelasi}

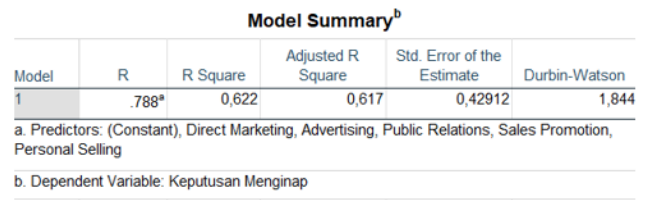


Dapat dilihat bahwa dari tabel di atas, hasil nilai Durbin- watson sebesar 1,844 yang memiliki arti tidak terjadi autokorelasi karena angka pada Durbinwatson yang berada diantara -2 sampai dengan 2.

\section{Tabel 18. Hasil Persamaan Regresi Linear Berganda}

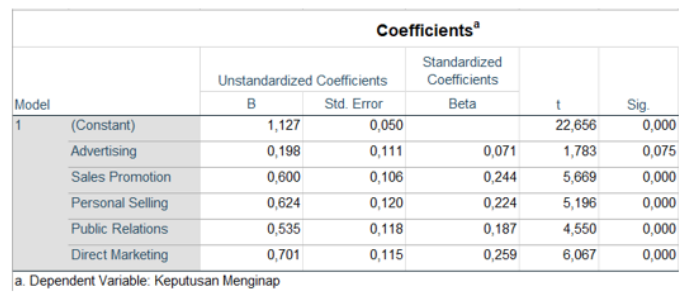

Nilai koefisien Advertising untuk variabel $\mathrm{X}_{1}$ sebesar 0,198 . Hal tersebut mengandung arti bahwa setiap peningkatan advertising dengan satu nilai maka variabel Keputusan Menginap (Y) akan naik sebesar 0,198 dengan asumsi bahwa variabel bebasyang lain dari model regresi ini adalah tetap

Nilai koefisien Sales Promotion untuk variabel $\mathrm{X}_{2}$ sebesar 0,600 . Hal tersebut mengandung arti bahwa setiap peningkatan Sales Promotion dengan satu nilai maka variabel Keputusan Menginap (Y) akan naik sebesar 0,600 dengan asumsi bahwa variabel bebas yang lain dari model regresi ini adalah tetap

Nilai koefisien Personal Selling untuk variabel $\mathrm{X}_{3}$ sebesar 0,624 . Hal tersebut mengandung arti bahwa setiap peningkatan Personal Selling dengan satu nilai maka variabel Keputusan Menginap (Y) akan naik sebesar 0,624 dengan asumsi bahwa variabel bebas yang lain dari model regresi ini adalah tetap
Nilai koefisien Public Relations untuk variabel X4 sebesar 0,535 . Hal tersebut mengandung arti bahwa setiap peningkatan Public Relations dengan satu nilai maka variabel Keputusan Menginap (Y) akan naik sebesar 0,535 dengan asumsi bahwa variabel bebas yang lain dari model regresi ini adalah tetap

Nilai koefisien Direct Marketing untuk variabel $\mathrm{X}_{5}$ sebesar 0,701. Hal tersebut mengandung arti bahwa setiap peningkatan Direct Marketing dengan satu nilai maka variabel Keputusan Menginap (Y) akan naik sebesar 0,701 dengan asumsi bahwa variabel bebas yang lain dari model regresi ini adalah tetap

\section{Tabel 19. Hasil Uji Koefisien Determinasi $\left(\mathbf{R}^{2}\right)$}

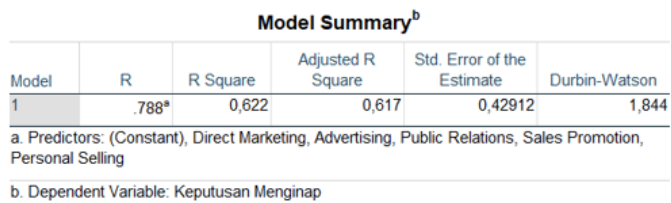

Koefisien determinasi $\left(\mathrm{R}^{2}\right)$ berfungsi untuk menghitung besarnya pengaruh seluruh variabel bebas terhadap variabel terikat.Berdasarkan Tabel 22 didapatkan hasil adjusted $\mathrm{R}^{2}$ (koefisien determinasi) sebesar 0,622. Artinya bahwa 62,2\% (Korelasi Kuat) variabel Keputusan Menginap (Y) akan dipengaruhi oleh variabel bebasnya, yaitu: Advertising $\left(\mathrm{X}_{1}\right)$, Sales Promotion $\left(\mathrm{X}_{2}\right)$, Personal Selling $\left(\mathrm{X}_{3}\right)$, Public Relations $\left(\mathrm{X}_{4}\right)$, dan Direct Marketing $\left(\mathrm{X}_{5}\right)$. Sedangkan sisanya sebesar $37,8 \%$ variabel Keputusan Menginap akan dipengaruhi oleh variabel-variabel yang lain yang tidak diteliti dalam penelitian ini.

Uji Pengaruh Simultan (Uji F) 
Uji ini berfungsi untuk mengetahui tingkat signifikansi pe $\mathrm{n}$ g a r u h variabel bebas secara simultan terhadap variabel terikat. Pengujian ini dilakukan pada tingkat keyakinan $95 \%$ dengan ketentuan sebagai berikut:

*Dengan menggunakan nilai probabilitas signifikansi

Jika tingkat signifikansi lebih besar

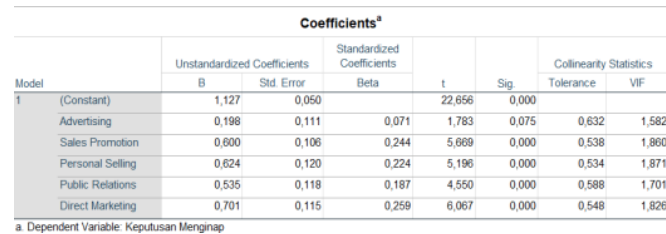
0,05 maka disimpulkan bahwa $\mathrm{H}_{0}$ diterima, $\mathrm{H}_{1}$ ditolak. Jika tingkat sebaliknya $\mathrm{H}_{1}$ diterima, signifikansi lebih kecil 0,05maka dapat disimpulkan bahwa $\mathrm{H}_{0}$ ditolak

Tabel 20.Hasil Uji Pengaruh Simultan (Uji F)

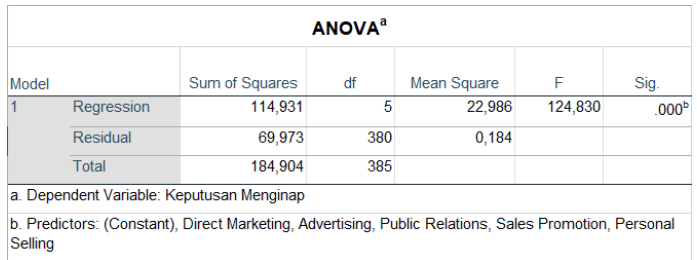

Dari hasil uji pengaruh simultan (uji F) tersebut dapat disimpulkan nilai signifikansi $=0,000<0,05$, maka Ho ditolak dan Ha diterima, atau dapat dikatakan variabel bebas yaitu Bauran Promosi (X) secara bersama-sama (Advertising, Sales Promotion, Personal Selling, Public Relations, dan Direct Marketing) berpengaruh signifikan terhadap variabel terikat yaitu Keputusan Menginap (Y).

Uji Parsial (Uji T) berfungsi untuk mengetahui a $\mathrm{pakah}$ masing-masing variabel bebas secara parsial mempunyai pengaruh yang signifikan terhadap variabel terikat. Adapun kriteria pengujian uji t yaitu sebagai berikut:

Jika signifikansi lebih kecil dari 0,05 maka H0 ditolak berarti tidak terdapat pengaruh signifikan variabel independen secara individual terhadap variabel dependen.

Jika signifikansi lebih besar dari 0,05 maka H0 diterima berarti ada pengaruh signifikansi variabel independen secara individual terhadap variabel dependen.

\section{Tabel 21. Hasil Uji Parsial (Uji T)}

Uji $\mathrm{T}$ dilakukan dengan membandingkan antara nilai signifikansi masing-masing variabel bebas dengan taraf kesalahan 5\% ( $\alpha=0,05)$. Berdasarkan hasil pengujian parsial (Uji T) dapat dilihat dari tabel 4.8 yang memperlihatkan bahwa:

$$
\text { Variabel Advertising (X1) }
$$

memiliki nilai signifikansi 0,075 lebih besar dari 0,05. Pengujian ini menunjukan bahwa H01 diterima dan H11 ditolak yang dapat disimpulkan bahwa Keputusan Menginap tidak dipengaruhi secara signifikan oleh Advertising. Berdasarkan jurnal (Ningsih \& Hati, 2017) yang memiliki kesimpulan yang sama mengenai advertising bahwa H01 diterima dan H11, yang memiliki arti bahwa dikatakan variabel advertising (X1) tidak memiliki pengaruh terhadap keputusan pembelian (Y).

Variabel Sales Promotion (X2) memiliki nilai signifikansi 0,000 lebih kecil dari 0,05. Pengujian ini menunjukan bahwa H02 ditolak dan $\mathrm{H} 12$ diterima yang dapat disimpulkan bahwa Keputusan Menginap dipengaruhi secara signifikan oleh Sales Promotion

Variabel Personal Selling (X3) memiliki nilai signifikansi 0,000 lebih 
kecil dari 0,05. Pengujian ini menunjukan bahwa H03 ditolak dan H13 diterima yang dapat disimpulkan bahwa Keputusan Menginap dipengaruhi secara signifikan oleh Personal Selling.

Variabel Public Relations (X4) memiliki nilai signifikansi 0,000 lebih kecil dari 0,05. Pengujian ini menunjukan bahwa H04 ditolak dan H14 diterima yang dapat disimpulkan bahwa Keputusan Menginap dipengaruhi secara signifikan oleh Public Relations.

Variabel Direct Marketing (X5) memiliki nilai signifikansi 0,000 lebih kecil dari 0,05. Pengujian ini menunjukan bahwa H05 ditolak dan H15 diterima yang dapat disimpulkan bahwa Keputusan Menginap dipengaruhi secara signifikan oleh Direct Marketing.

\section{SIMPULAN DAN SARAN}

\section{Simpulan}

Berdasarkaan hasil penelitian yang dikerjakan dengan metode penelitian kuantitatif dan teknik penyebaran yang digunakan adalah angket yang dilakukan di Hotel mengenai bauran promosi yang sudah diberikan terhadap keputusan menginap tamudapat diambil kesimpulan yang akan dipaparkan sebagai berikut:

Variabel Advertising (X1) memiliki nilai signifikansi 0,075 lebih besar dari 0,05 yang menunjukan bahwa H01 diterima dan $\mathrm{H} 11$ ditolak yang dapat disimpulkan bahwa Keputusan Menginap tidak dipengaruhi secara signifikan oleh Advertising.

Variabel Sales Promotion (X2) memiliki nilai signifikansi 0,000 lebih kecil dari 0,05 yang menunjukan bahwa H02 ditolak dan H12 diterima yang dapat disimpulkan bahwa Keputusan Menginap dipengaruhi secara signifikan oleh Sales Promotion.
Variabel Personal Selling (X3) memiliki nilai signifikansi 0,000 lebih kecil dari 0,05 yang menunjukan bahwa H03 ditolak dan H13 diterima yang dapat disimpulkan bahwa Keputusan Menginap dipengaruhi secara signifikan oleh Personal Selling.

Variabel Public Relations (X4) memiliki nilai signifikansi 0,000 lebih kecil dari 0,05 yang menunjukan bahwa H04 ditolak dan H14 diterima yang dapat disimpulkan bahwa Keputusan Menginap dipengaruhi secara signifikan oleh Public Relations

Variabel Direct Marketing (X5) memiliki nilai signifikansi 0,000 lebih kecil dari 0,05 yang menunjukan bahwa H05 ditolak dan H15 diterima yang dapat disimpulkan bahwa Keputusan Menginap dipengaruhi secara signifikan oleh Direct Marketing.

Dari hasil uji pengaruh simultan (uji F) tersebut dapat disimpulkan nilai signifikansi $=0,000<0,05$, maka $\mathrm{Ho}$ ditolak dan $\mathrm{Ha}$ diterima, atau dapat dikatakan variabel bebas yaitu Bauran Promosi (X) secara bersama-sama (Advertising, Sales Promotion, Personal Selling, Public Relations, dan Direct Marketing) berpengaruh signifikan terhadap variabel terikat yaitu Keputusan Menginap (Y).

\section{Saran Untuk Penelitian Selanjutnya:}

a. Hotel harus meningkatkan periklanan dengan cara memperbaiki dari sisi pemberian pesan yang lebih mudah dimengerti dan menarik tamu, ketepatan iklan dalam memberikan informasi kepada konsumen dan mengajak konsumen untuk menggunakan produk atau jasa, dan memperbaiki sasaran dalam hal ketepata sasaran periklanan melalui media.

b. Contoh penggunaan promosi penjualan di Hotel Santika Premiere 
Slipi, Jakarta yakni hari libur nasional akan digunakan sebagai sarana potongan harga atau memberikan poin setiap kali menginap. di Hotel Santika Premiere Slipi, Jakarta harus selalu mempertahankan daya Tarik program potongan harga maupun reward agar dapat menarik keputusan tamu untuk menginap

c. Staf Hotel Santika Premiere Slipi, Jakarta harus terus mempertahankan pemahaman pelanggan mengenai produk hotel yang dipunyai agar bisa memberikan pemahaman dan membuat pelanggan lebih tertarik mengenai produk hotel dan meningkatkan terus keputusan menginap tamu.

d. Hotel Santika Premiere Slipi harus terus mempertahankan dan mengembangkan sisi program untuk mempengaruhi persepsi, opini, dan keyakinan akan produk agar lebih meningkatkan tingkat hunian kamar dan keputusan menginap tamu

e. Hotel Santika Premiere Slipi harus terus mempertahankan pemasran langsung yang dilakukan sekarang karena peneliti melihat bahwa ketepatan penggunaan alat pemasaran langsung, seperti telepon dan email sangat efektif dan dominan sehingga menciptakan tingkat huniankamar dan keputusan menginap tamu yang meningkat

\section{Buku:}

\section{DAFTAR PUSTAKA}

Fraenkel, J. R., \& Wallen, N. E. (1990). How to Design and Evaluate Research In Education 8th Edition. Boston: McGraw-Hill Higher Education.

Kotler, Philip dan Amstrong, Gary, 2012, Prinsip-Prinsip Pemasaran, Edisi 13, Jilid 2, Erlangga, Jakarta.
Kotler, Philip dan Kevin L. Keller, 2009, Manajemen Pemasaran Edisi 12 Jilid 2. PT Indeks, Jakarta.

Purwana.D, Rahmi.R., \& Aditya.S, 2017, Pemanfaatan Digital Marketing Bagi Usaha Mikro, Kecil dan Menengah (UMKM) di Kelurahan Malaka Sari, Duren Sawit. Jurnal Pemberdayaan Masyarakat Madani (JPMM).

Sugiarto.T dan Sudibyo.D, 2015, Metode Penelitian Hospitality Pariwisata. PT Matana Publishing Utama, Tangerang.

Sugiyono,2013,Metode Penelitian Pendidikan (Pendekatan Kuantitatif, Kualitatif, dan R\&D), Alfabeta, Bandung.

Sugiyon, 2014, Metode Penelitian Pendidikan Pendekatan Kuantitatif, Kualitatif Dan R\&D Alfabeta, Bandung.

Taprial.V and Kanwar.P, 2012, Understanding Media Social, ISBN13:978876819927, BookBoon.

Jurnal:

abdillah, m., kasmita, \& abrian, y. (2014). pengaruh bauran promosi terhadap keputusan tamu untuk menginap di hw hotel padang. Jurusan Kesejahteraan Masyarakat

aprilukito, j., simatupang, v., \& suparman,m. (2017). kegiatan sales call dalam penjualan kamar di grand hotel lembang. sekolah tinggi pariwisata bandung, 132

Molika, E., abdillah, y., \& pangestuti, e. (2017). pengaruh bauran promosi hotel terhadap keputusan menginap business traveler di hotel bisnis. studi pada tamu hotel ibis surabaya city center.

Ningsih, y. p., \& hati, s. w. (2017). pengaruh bauran promosi terhadap keputusan pembelian produk accu yuasa yang dipromosikan distributor pt riau indotama

ningsih, y. p., \& hati, s. w. (2017). pengaruh bauran promosi terhadap keputusan pembelian produk accu 


\section{Versi Online:}

https://journal.ubm.ac.id/index.php/hospitality-pariwisata Doi: http://dx.doi.org/10.30813/jhp.v8i1.3205

Hasil Penelitian

yuasa yang dipromosikan

distributor pt riau indotama

Ristania, Novia dan Jerry Justianto. 2014. Analisis Pengaruh Harga, Promosi Dan Viral Marketing Terhadap Keputusan Pembelian Pada " Online Shop" SNexian Melalui Facebook. Jurnal of Business Strategy and Execution, Vol 5 No.2 2014, ISSN 131-16,

\section{Rujukan Elektronik}

Badan Pusat Statistik. (2019). Retrieved from:https://lokadata.beritagar.id/c hart/preview/tingkat-hunian-hotelberbintang-di indonesia-20172018-1549942227

Badan Pusat Statistik. (2019). Tingkat Penghunian Kamar Hotel 2019.

https://www.kemenparekraf.go.id/.Retriv ed 5 4, 2021, from https://www.kemenparekraf.go.id https://www.kemenparekraf.go.id/ post/statistik-tingkat-penghuniankamar-hotel-bintang-tahun-2017

Syafnidawaty. (2020, 10 23). https://raharja.ac.id/. Retrieved fromhttps://raharja.ac.id/2020/10/2 3/manfaat-penelitian/ 